aehe

Investigaciones de Historia Económica - Economic History Research

Asociación Española de

Historia Económica

Artículo

\title{
On plague and Ebola in a time of COVID-19
}

\section{Cormac Ó Gráda* \\ University College Dublin}

\section{ARTICLE INFO}

\section{Article history:}

Reception: 14 abril 2020

Acceptance: 15 septiembre 2020

On-line: 1 diciembre 2020

\section{JEL classification:}

I1

I18

N17

N37

Keywords

Plague

Mortality

Health

Economic history

\section{Códigos JEL:}

I1

I18

N17

N37

Palabras clave:

Plaga

Mortalidad

Salud

Historia económica

\begin{abstract}
A B S T R A C T
The global COVID-19 pandemic recalls the Ebola epidemic of 2014-15 and earlier much more lethal plague epidemics. All share several characteristics, even though the second and third plague epidemics dwarfed the both the 2014-15 Ebola outbreak and COVID-19 in terms of mortality. This essay reviews the mortality due to Ebola and plague and their lethality; the spatial and socioeconomic dimensions of plague mortality; the role of public action in containing the two diseases; and their economic impact.
\end{abstract}

@ 2020 Asociación Española de Historia Económica

\section{Sobre la plaga y el ébola en tiempos de COVID-19}

\section{R E S U M E N}

La pandemia global de COVID-19 recuerda a la epidemia de ébola de 2014-15 y a epidemias pasadas mucho más letales. Todas ellas comparten varias características, incluso aunque la segunda y tercera epidemias de peste empequeñezcan tanto al brote de ébola de 2014-15 como al de COVID-19 en términos de mortalidad. Este ensayo revisa la mortalidad consecuencia del ébola y de la peste y su letalidad; las dimensiones espaciales y socioeconómicas de la mortalidad; el rol de las acciones públicas conteniendo ambas enfermedades, y su impacto económico.

\footnotetext{
* Corresponding author. Email: cormac.ograda@ucd.ie
} 


\section{Introduction}

Before COVID-19, the last epidemic to command global attention was the 2014-15 Ebola epidemic. Ebola attracted global attention for its highly infectious character, its high fatality rate, the lack of any known cure for it, and the grave risks that it posed for health workers and third parties. The fears that it generated and the strict public health measures that it prompted echoed responses to the medieval Black Death and the third plague pandemic that originated in China in 1855, and far outweighed those to COVID-19.

Ebola and plague have rather similar incubation periods and both cause painful and distressing deaths. Indeed, for a time in the 2000s, some experts were convinced that plague was a form of Ebola (Little, 2011; Haensch et al., 2010). Ebola, like COVID-19, is transmitted from person to person; whereas that is literally true of only one rare and highly lethal form of plague, pneumonic plague. However, the relatively recent finding (Drancourt et al., 2006; Ayyadurai et al., 2010; Hufthammer and Walløe, 2013) that plague can be transmitted by body lice -and does not require the presence of rats and rat fleas-implies a route approximating transmission from person to person ${ }^{1}$.

As in the case of COVID-19, both plague and Ebola led to urgent searches for a medical remedy: rapid in the case of plague in the late 1890 s once the bacillus responsible had been discovered, and similarly rapid in the wake of the 2014-15 crisis with the preparation for use of the (previously discovered) VSV-EBOV vaccine. These common characteristics prompt the following reflections about plague and Ebola, even though the second and third plague epidemics dwarfed the 2014-15 Ebola outbreak in terms of mortality. With COVID-19 in mind, I review the mortality due to plague and Ebola and their lethality; the spatial and socioeconomic dimensions of plague mortality; the role of public action in containing the two diseases; and their economic impact ${ }^{2}$.

\section{Deaths from Plague and Ebola}

At first quite alarming predictions were being made about the likely spread of Ebola in western Africa and beyond. Econometric simulations were forecasting that if the disease spread, one million or more would die "in the next six months", forecasts soon echoed by the U.S. Centers for Disease Control and Prevention (CDC). The World Health Organization's mid-October 2014 forecast of 10,000 new cases weekly was more modest, although it still dwarfed the actual cumulative out-turn of about 30,000 cases and over 11,000 deaths (roughly $0.05 \%$ of the combined population of the three affected countries) (Kupferschmidt, 2014; Corsi, 2014; Weintraub, 2014; Sengupta, 2014). Academic predictions, based on shaky assumptions and extraordinarily unrealistic in retrospect, were not published in order to cause panic; but they were recycled by doomsayers for their "shock value" and unwittingly served as stimulants to public and private action (Grady, 2014; Nordrum, 2015; Glennerster et al., 2014; Johnson, 2014).

\footnotetext{
1 See Kool (2005). Giovanni Boccaccio (author of the Decameron) believed that "the malady was communicated by speech or association with the sick [...] or by touching the clothes of the sick", which led people "to shun and abhor all contact with the sick and all that belonged to them, thinking thereby to make each [their] own health secure".

${ }^{2}$ For an excellent earlier essay relating the two diseases see Green (2014).
}

Whereas demographic data on Ebola (and COVID-19) are plentiful, historians of the Black Death have very little solid data to work on. This is particularly so in the case of the first wave of the plague called the Black Death that hit the Middle East and Europe in 1347-513. After a careful scrutiny of the evidence for England nearly four decades ago medievalist John Hatcher (1977, pp. 21-25) declared the "most judicious" estimate of excess mortality from that first outbreak in Europe in 1348-51 to be $30-45 \%$. Malanima's analysis of country-level data implies that the Black Death and secondary epidemics reduced Europe's population by $28 \%$ between 1300 and 1400 (Malanima, 2012, p. 314), but with considerable variation across countries, ranging from only $10 \%$ in Austria (including Bohemia and Hungary) and $14 \%$ in Belgium to $44 \%$ in Scandinavia and 50\% in Ireland. More recent estimates also range widely, from a third to over three-fifths (Rawcliffe et al., 2015; Campbell, 2016). In aggregate, these guesstimates suggest that the first outbreak of the Black Death reduced Europe's pre-plague population of about 80 million by between 25 and 50 million ${ }^{4}$.

The Norwegian plague historian Benedictow bases his case for the upper-bound estimate of at least three-fifths on what he interprets as "the remarkable similarity of the levels of mortality in [...] widespread and diverse regions", although some critics have linked this "similarity" to Benedictow's dismissal of any inconvenient data implying lower mortality (Benedictow, 2004, pp. 381-83; Cohn, 2005; Horrox, 2006, p. 199; Noymer, 2007, p. 623-624; Mengel, 2011, pp. 22fn74, 32fn110). More recent work on Central Europe suggests that the Black Death's impact there has been "greatly exaggerated" (ibid., 2011, pp. 31-32). But in the absence of anything remotely resembling civil registration the evidence is very thin and selective.

One way of evaluating the plausibility of a population decline of three-fifths is to ask how would it have impacted on the size and distribution of income. The economic impact of the Black Death in its wake was certainly dramatic. Clark reckons that the real wages of agricultural labourers in England rose by 55.5\% between 1339-48 and 1349-58, while real rents fell by $30 \%$ (Clark, 2007, p. 133; 2001, p. 25); according to Malanima (2007, p. 157-58) the real wages of Italian urban workers rose by about $35 \%$ and those of rural workers by $63 \%$ over the same period (see too Pamuk 2007). These are big changes, but how do they square with Benedictow's 60\% decline in population?

Table 1 reports the predicted outcomes for a range of population losses and the elasticity of substitution associated with the Constant Elasticity of Substitution production function:

$$
Q=E\left(a L^{\rho}+b(T+K)^{\rho}\right)^{1 / \rho}
$$

where $E$ is a measure of efficiency, $Q$ is output, $L$ (labour), $T$ (land), and $K$ (capital) are the factors of production and $a$, and $b$ are factor shares (here both assumed to be 0.50 ). In this specification the elasticity of substitution, $\sigma$, equals $1 /(1-\rho)$. Let initial $E, L, K$, and $T$ equal 1 , and assume that the Black Death affected only $L$, which is a constant proportion of the population (compare Hirshleifer, 1966); the effect of a reduction in $L$ then depends on factor shares and $\rho$. Using 0.5 for factor shares

\footnotetext{
${ }^{3}$ The focus here is on Europe but it bears noting that the first wave was also devastating in the Middle East and that some of the later waves were just as murderous as the first.

${ }^{4}$ Excluding Russia. See Malanima (2012, p. 312).
} 
assumes constant returns to scale. In that case the post-Black Death wage, $w_{1}$, equals $\left[1 / L_{1}\right]^{1-\rho}$. As seen in Table 1 , the actual changes in wages are much more modest than those implied by Benedictow's $60 \%$ decline in population (i.e. $L_{1}=0.4$ ) for a plausible range of $\sigma(0.8<\sigma<1.5)$. The $50 \%$ or so rise in wages implied by Clark and Malanima is more consistent with $L_{1}=0.6$, or a $40 \%$ loss in population.

\section{Table 1}

Predicted wage increase for different values of $L_{1}$ and $\sigma$

\begin{tabular}{|c|c|c|c|}
\hline $\boldsymbol{L}_{\mathbf{1}}$ & $\square=\mathbf{1 . 5}$ & $\square=\mathbf{1}$ & $\square=\mathbf{0 . 8}$ \\
\hline 0.8 & 16 & 25 & 32 \\
\hline 0.6 & 41 & 67 & 89 \\
\hline 0.4 & 89 & 150 & 214 \\
\hline
\end{tabular}

\section{Relative Lethality}

Although some contemporaries believed in selective recovery from the Black Death (Crespo and Lawrenz, 2014), most highlighted its lethality, i.e. the high probability that those who were infected would die from it. Hard data on the lethality of the Black Death in the fourteenth century are lacking. Paul Slack states that "in the absence of appropriate treatment, between $40 \%$ and $60 \%$ of the victims die", but Benedictow, perhaps because his mortality estimate would require a very high fatality rate indeed to be plausible, invoked that of nearly four-fifths recorded during the Bombay Presidency pandemic of 18961900 (Slack, 2012, p. 5; Benedictow, 2004, p. 9; compare Nathan, 1898, pp. 13-14; Fee, 1900). Benedictow might equally have invoked the case-fatality rates recorded for the Chinese population of Hong Kong between 1894-1907-92\%. But then would he not also have had to take into account the much lower fatality rate of Hong Kong's non-Chinese population-59\% (Brown, 1913; Pryor, 1975; Benedict, 1996, pp. 142, p. 206fn10)and the accompanying implication that the health and nutritional status of the populations at risk may have mattered?

An added complication-also pertinent to Ebola-is whether lethality varied during the course of an epidemic. Hatcher (2008: 208) suggests that as the first outbreak in 1348 abated "the battle between the frailty of the victims and the potency of their affliction began to become less unequal". Similarly, towards the end of the Moscow outbreak of 1771-72 "several persons who had the plague were but slightly indisposed, and walked about though they had buboes upon them" (Alexander, 2003, p. 2006)5. Moreover, there is the following tantalizing claim by the pope's surgeon regarding the lethality of successive outbreaks of plague in fourteenth-century Avignon (as cited in Cohn, 2008): "In 1348, two thirds of the population were afflicted, and almost all died; in 1361, half the population contracted the disease, and very few survived; in 1371, only one tenth were sick, and many survived; while in 1382, only one twentieth of the population became sick, and almost all of these survived".

The death rates recorded in Italian lazaretti (pest houses) in the seventeenth century were much lower than Benedictow's four-fifths. However, as Cipolla has made clear, rates such as

\footnotetext{
${ }^{5}$ For a similar assertion referring to the outbreak of 1665 in London see Payne (1894, p. 94)
}

the one-half recorded in the lazaretto (or pest-house) of Pistoia in 1630-31 may underestimate the plague's lethality, for two reasons. First, the survivors included many people who were quarantined because they displayed symptoms mistaken for plague or had resided with plague victims and, second, an unknown number had already died of the plague before they could be sent to the lazaretto (Cipolla, 1973, p. 105; 1981, p. 65). Whether such considerations are enough to bridge the gap between 50 and $80 \%$ remains moot $^{6}$. Note too the remarks of Russian physician Orraeus, who whilst accompanying troops wrote during the 1770-72 plague: "Of our sick infected by the plague, one can calculate that a third recover; but of the local inhabitants, much the greater part die of it, because their relatives in this case immediately abandon them, besides which they do not take any medicine" (cited in Alexander, 2003, p. 105). Today the WHO reckons that half of those struck by plague recover without the aid of any medical treatment, a further indication that factors such as nutritional status and health offer some resistance against Yersinia pestis. During the 2014 outbreak of bubonic plague in Madagascar 119 confirmed cases resulted in 40 deaths; an outbreak in August-September 2015 , this time of the pneumonic form, killed 10 of 14 victims.

The shifting lethality of the influenza pandemic of 1918-19 is another case in point. Lethality increased dramatically between the first onset in mid-1918, when relatively few succumbed, and the second wave some 4-6 months later. Precision is impossible since both incidence and the number fatalities are in dispute, but a global fatality rate of about $6-8 \%$ seems reasonable (30-40 million deaths from 500 million cases). Here, too, one suspects that nutritional and health status mattered; in Bombay/Mumbai, for example, in 1918-19 there were 8.3 deaths per thousand among Europeans, 9.0 per thousand among Parsees, 18.9 per thousand among caste Hindus, and 61.6 per thousand among low caste Hindus (Phipson, 1923, pp. 517-519). It seems unlikely that differences in cross-communal incidence alone could account for such contrasts in morality.

The paucity of standard documentary evidence enhances the value of some recent archaeological research on the lethality of the fourteenth-century Black Death. Sharon DeWitte and her colleagues have compared skeletal evidence from London's East Smithfield plague cemetery and non-epidemic samples from medieval cemeteries in the Danish towns of Viborg and Odense in order to test for whether those who succumbed to plague were more likely to have suffered from other health problems in the past (DeWitte and Wood, 2008; DeWitte and Hughes-Morey, 2012; DeWitte and Slavin, 2013). Their findings also argue against the case for no selection. They report that "people who experienced physiological stressors, and who developed stress markers in response to those stressors, at some point (perhaps even long) before the arrival of the epidemic were subsequently more likely to die during the Black Death compared to their peers who lacked the stress markers" (DeWitte, 2014, p. 114). The finding is intriguing, although whether the economic and environmental pressures endured by Londoners, of whom there were about one hundred thousand on the eve of the Black Death, approximated those facing the people buried in Odense and Viborg, both towns with populations of a few thousand inhabitants at most, is moot.

\footnotetext{
${ }^{6}$ Nearly two-thirds of those quarantined in Moscow in 1771-72 did not survive (Alexander, 2003, p. 226).
} 


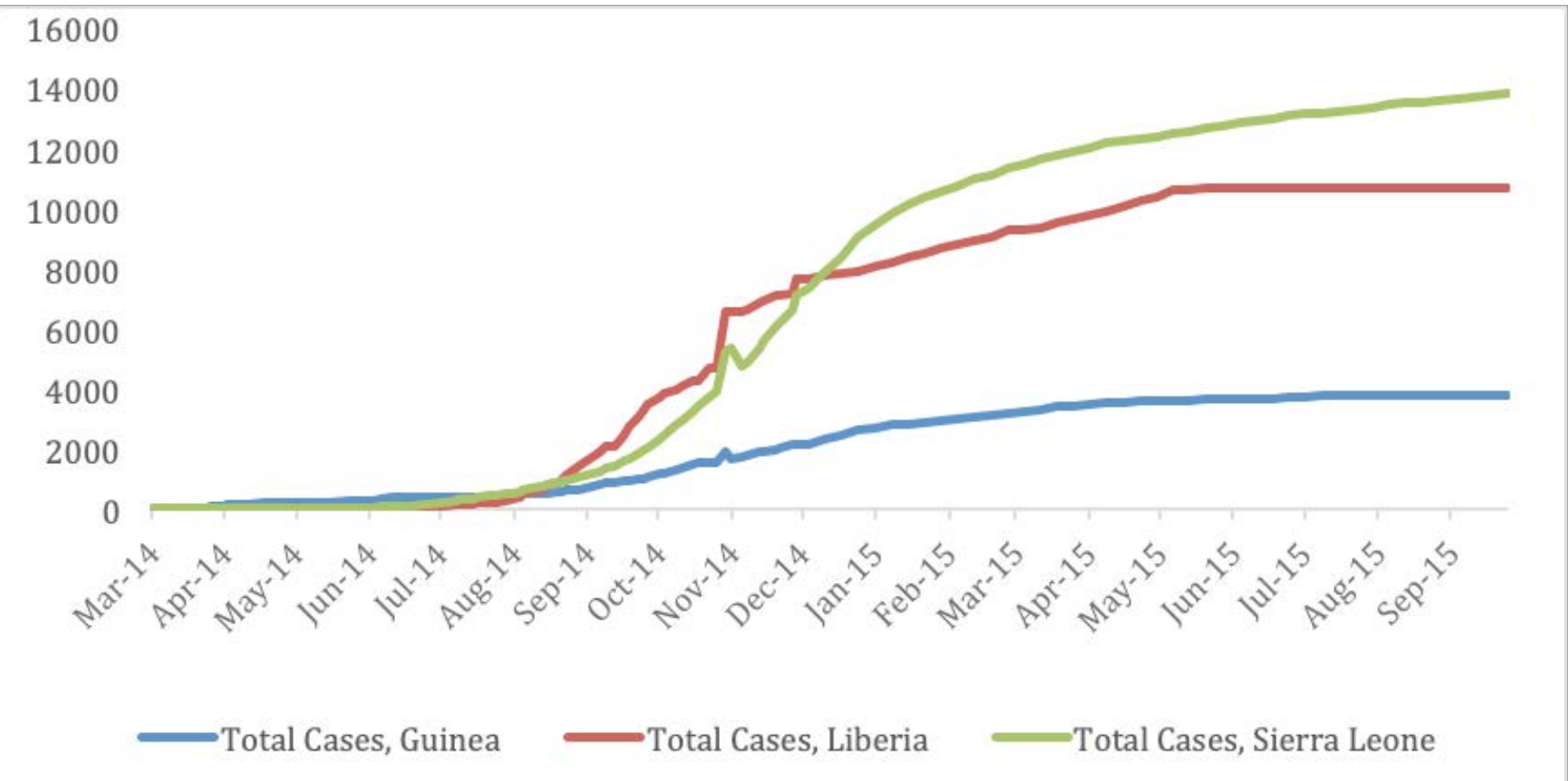

Figure 1a. Cumulative cases in Guinea, Liberia and Sierra Leone.

Source: WHO, Ebola Situation Reports.

\section{Fatality Rates 2014-2015}

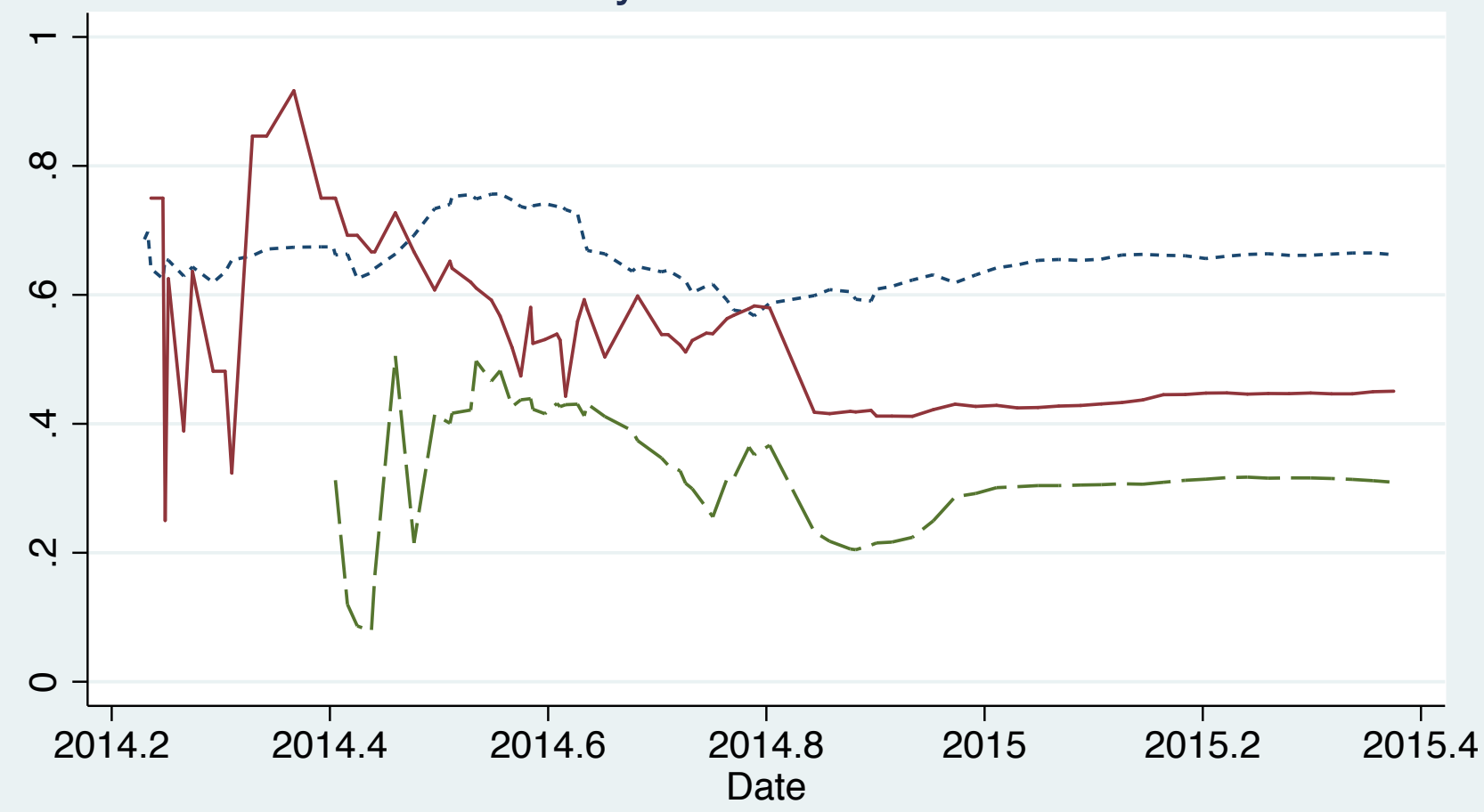

Figure 1b. Cumulative fatality rates in Guinea, Liberia and Sierra Leone.

Source: WHO, Ebola Situation Reports. 


\section{Table 2}

The Recent Ebola Epidemic: Cases and Deaths

\begin{tabular}{|c|c|c|c|c|c|c|}
\hline & \multicolumn{3}{|c|}{ All } & \multicolumn{3}{|c|}{ Health Workers } \\
\hline & Cases & Deaths & $\%$ & Cases & Deaths & $\%$ \\
\hline Guinea & 3,800 & 2,534 & 66.7 & 196 & 100 & 51.0 \\
\hline Sierra Leone & 13,982 & 3,955 & 28.3 & 307 & 221 & 72.0 \\
\hline Total & 28,454 & 11,297 & 39.7 & 881 & 513 & 58.2 \\
\hline
\end{tabular}

Source: http://apps.who.int/ebola/current-situation/ebola-situation-report-14-october-2015

My reading of the scant evidence is that both the mortality and lethality rates associated with bubonic plague are likely to have varied across Europe. Yet even though Benedictow's estimate of mortality, if not also that of lethality, seems on the high side, his depiction of the first outbreak of the Black Death as "the greatest catastrophe ever" is apt. No other disaster in European history-war, famine, or epidemic-matches it. The Black Death was unparalleled because it was so easy to transmit and because of its power to kill.

Before the 1890s the only half-effective cure against the bubonic plague was to lance the buboes, an extremely painful procedure which apparently reduced the fatality rate (but compare Boghurst 1894, pp. 87 and 89). The fatality rate from Ebola in 2014-15 was much lower than that from untreated Yersinia pestis (Table 2). The fatality rate was also very variable between the three countries affected by the pandemic, but lower everywhere than in the Republic of the Congo in 2002-4 (where out of 178 reported cases, 157 resulted in death) (Fink, $2014)^{7}$. World Health Organization data suggest that the overall fatality rate during the recent outbreak was $40 \%$, ranging from $29 \%$ in Sierra Leone to $67 \%$ in neighbouring Guinea (see Table 2 and Figure $1 \mathrm{~b}$ ). There were 36 cases and 15 deaths outside the three countries. Neighbouring Nigeria and Mali accounted for 28 of those cases and 14 of the deaths. Do these numbers reflect differences in reporting practices across the three countries? Or was the relatively low lethality in Sierra Leone due to more effective medical care? We do not know, but if the huge range in the ratio of reported deaths from COVID-19 to reported cases is indicative, both factors probably played a role ${ }^{8}$.

A second striking and disturbing implication of Table 2 is the very high proportion-nearly $5 \%(513 / 11,297)$-of health workers among those who died during the Ebola outbreak. Not only that: the numbers imply that the deaths represented a significant share of medical personnel. In Guinea, for example, there were 977 medical doctors and 4,765 nurses in $2015^{9}$. Nearly all the health workers who succumbed were native-born: five health workers from high-income countries contracted the disease, and only one died. Health workers'

\footnotetext{
7 On the Republic of the Congo see WHO (2003), updates 7 May 2003 and 6 January 2004.

${ }^{8}$ As of July $30^{\text {th }} 2020$ the ratio ranged from $0.05 \%$ in Singapore and 0.36 in Bahrain to $15-16 \%$ in the UK and France and $28 \%$ in Yemen (New York Times, July $30^{\text {th }} 2020$ ).

${ }^{9}$ The data may be obtained at: https://apps.who.int/gho/data/node.main. HWFGRP?lang=en.
}

share of all Ebola deaths ranged from 3.9\% in Guinea $(100 / 2,534)$ to $5.6 \%(221 / 3,955)$ in Sierra Leone. Nor were the victims confined to the lowest-paid workers: in Sierra Leone they included several physicians. These are very high proportions, given that transmission requires physical contact (WHO, 2015). Perhaps the cumbersome procedures involved in "donning and doffing" the highly uncomfortable Ebola protective suits worn by over-stretched health workers led some to take short cuts? (Kitamura, 2014) The vulnerability of health workers, even in rich economies, was also a feature of COVID-19.

Equally striking are the fatality rates among health workers struck by Ebola and the big gap between fatality rates in Guinea (less than half) and Sierra Leone (over seventy\%). In Liberia and Sierra Leone health workers who contracted Ebola were more likely to die of it than others, even though presumably they were more likely to be diagnosed early. In all three countries, moreover, WHO data imply the fatality rate among health workers grew worse as the outbreak progressed. In Guinea it rose from 59\% before 26 November 2014 to $77 \%$ thereafter; the percentages in Liberia were 42 and 51, respectively, and in Sierra Leone 21 and 36.

Despite this, the risk to health workers seems to have decreased over time, because WHO data imply that they were less likely to contract it over time. Thus, up to 26 November 2014 , health workers represented nearly six\% of all deaths, but thereafter-when presumably they were much more numerous-they represented about three\%. Conditions "improved" in all three countries in this regard. The risks faced by health and care workers during the COVID pandemic have been highlighted in the media, but it is too early to pronounce on death rates.

\section{Did the Plague Distinguish Between Rich and Poor?}

The greater vulnerability of the elderly and those with a pre-existing health condition to COVID-19 is well known, and there is evidence too that the poor are at greater risk than the rich (UN, 30 June 2020). Casadaban, who died of Yersinia pestis in Chicago in 2009, was a most unlikely plague victim. A biology professor, he succumbed to accidental exposure to a strain of the virus in his lab. The plague bacillus was blind, and during the first outbreak of the Black Death "top people" such as the parents and siblings of Florentine merchant Datini; the renowned Italian canonist d'Andrea; Joan, daughter of daughter of Edward III and his wife, Philippa of Hainault; Eleanor of Portugal, queen of Aragon; and two archbishops of Canterbury who died in rapid succession, were not exceptional. But were the most likely victims of plague always disproportionately the 
poor? Alfani and Murphy (2017, p 236) argue that the first wave was a universal killer but that the disease affected less to the rich in subsequence waves, probably because they learnt how to deal with the disease. That was almost certainly the case during the last outbreaks of plague in England in the seventeenth century. In Noorthouck's account of the last London outbreak, "the distemper was left chiefly to prey upon the common people; which it did to a degree, as to obtain the name of the poor's plague" (Cummins et al., 2016; Noorthouck, 1773, p. 220).

Cipolla's study of plague in Prato in 1630 revealed that among those who fought it, the elite (health officers, physicians) were hardly touched while "the gravediggers and the attendants in the pest-house died like flies" (Cipolla, 1973, pp. 107-08). During the last outbreaks of plague in London searchers and especially corpse bearers were presumably at similar risk, but according to court publisher L'Estrange the attack of 1665 took away no "person of prime authority and command". Again, in Moscow in 1770-1 the plague, "as is generally the case, raged chiefly among the common people; the nobles and better sort of inhabitants escaped the contagion, a few only excepted, who fell victims to their rashness and negligence [...] Amid so great a number of deaths, $[\ldots]$ there were only three persons of family, few of the principal citizens, and not more than 300 foreigners of the common class, who fell victims to the plague; the rest consisted of the lowest order of the Russian inhabitants" (de Mertens 1799, pp. 34-35). During the third pandemic in Hong Kong the white population escaped almost unscathed, and the small number who contracted plague were much less likely to die of it than the Chinese. An American public health specialist found this "interesting and strange", given that "the white man has mixed freely with the Chinaman, going in and out of Chinatown at all hours, and many of them have their places of business within the infected areas; and yet they escape infection" (Brown, 1913, pp. 555-56).

Parish register data shed further light on the socioeconomic gradient of plague mortality in sixteenth and seventeenth-century London. One of the most striking features of the data is the sharp fall between the 1560s and 1660s in mortality in the richer intramural parishes. An increasing tendency for the better off to flee from the city during plague years may help account for this. In 1665 the exodus included the King and his court (with Charles II manifesting a "paternal regard" for his subjects from a safe distance in Oxford), "almost all the rich", and "a great many of the clergy who were in circumstances" (Harvey, 1769, pp. 415-16). Note conversely the significant increase over time in mortality in London's rapidly urbanizing out-parishes. Another likely reason for the socioeconomic gradient is the increasing self-segregation of the rich in London over time (Cummins et al., 2015).

Alfani and Bonetti's (2015) analysis of an unusually rich dataset from the town of Nonantola in northwestern Italy during the plague epidemic of 1630-31 seems to be the exception, in that in Nonantola the rich were at as much risk as the poor and, indeed, the richest part of the town is where the risk of dying from plague was highest.

\section{How Did the Plague Spread?}

Unlike COVID-19, Ebola did not spread through casual contact or close physical proximity to others; it required direct contact with the bodily fluids of an infected person. This made it easier to contain. Ebola's erratic advance and retreat in 201415 prompts a reflection on the spread of plague during its last visitations. The first named casualty of the last outbreak in London died in the low-income and densely populated parish of St. Giles-in-the-Fields, located to the northwest of the old walled city, on Christmas Eve 1664 (Moote and Moote, 2006). This case raises two issues. First, it was claimed at the time that there was an apparent gap in plague deaths between then and 9 February 1665 and thereafter until 22 April 1665. Was the long hiatus between the first death due to "a hard frost which set in this winter and continued till March 1665; when its virulence was revived by the advance of the spring" (Noorthhouk, 1773, p. 217)? Or was it due to people concealing the truth from the officials responsible for recording the data, "as people were very loth at first to have neighbours believe their houses were infected, by money, or by other means they procured the dead to be returned as dying of other distempers" (Harvey, 1769, p. 439)? The London Bills of Mortality, a weekly record of deaths by cause, have always been considered a useful but fallible source on the demography of the plague. That is why the attempt by Cummins et al. (2015) to track London's last plague epidemics over time and across parishes supplements what can be safely inferred from the bills with burial data from surviving parish registers.

The second is the location of the deaths. A contemporary described the London outbreaks of 1603 to 1636 as beginning "the first time by a surfeit in White Chapell, the second time, by Seamen, about the same place, the third by reason of rotten mutton at Stepney, the fourth with a packet of carpets from Turkey, the fifth with a Dogge that come over from Amsterdam" (cited in Brett-James, 1935, p 205). The London apothecary William Boghurst (1894, p. 26), however, noted that "the Plague hath put itself forth in St. Giles's, St. Clement's, St. Paul's, Covent Garden, and St. Martin's this 3 or 4 years, as I have been certainly informed by the people themselves that had it in their houses in those Parishes"10. This suggests a combination of local and exogenous factors, as does Payne's introduction to Boghurst (1894, pp. xiv-xv), although the consensus on London's last epidemics is that "the plague is never originally bred with us but always brought accidentally from abroad" (Harvey, 1769).

The link between the outbreak of 1665 and "the transport of infection from Smyrna to Amsterdam in 1663" (Slack, 1981, p. 470) is plausible. But there is a conundrum; if indeed plague reached England from the continent (i.e. Holland), the first outbreak would most likely have occurred in some docklands parish. Why Saint-Giles-in-the-Field in the West End? Can we credit the story that it originated there with "some Levant goods that came from Holland [...] carried to a house in Long Acre near Drury Lane, where they were first opened", whereupon "two Frenchmen" died there and another who fled from Drury Lane to Bearbinder Lane introduced the plague into the city (Noorthhouck, 1773, p. 217), a story which according to Payne (in Boghurst, 1894, pp. xi-xii) is "not supported by any authentic data"?

In their study of the spread of infection across the city weekby-week Cummins et al. (2015) infer the location of the last outbreaks of plague from an epidemiological model applied to

\footnotetext{
${ }^{10}$ In the Dictionary of National Biography entry on Boghurst, Paul Slack, the greatest living expert on the history of plague, deems Boghurst "the most reliable eyewitness account of bubonic plague in 1665 ".
} 
parish burial data. They find that these outbreaks were indeed more likely to start in the poor northern suburbs, before spreading around the walls and then within the City proper. In no case did mortality first appear in dockland parishes, implying that-perhaps-plague could have been generated internally in response to local conditions. This would support a "localist" rather than a "contagionist" interpretation of the spread of plague in 1665 , whereby the plague had localized in rural rodent populations ${ }^{11}$. Interestingly, l'Estrange's Intelligencer noted that the plagues of 1625 and 1636 had broken out "among the Butchers of White-Chapel (the likeliest Place for it always to shew itself here in) where there could not be least Suspicion of Foreign Goods".

Benedictow's claim that the incidence of plague was similar across "widespread and diverse regions' is not borne out by the spatial variation in mortality in early modern London and in sixteenth- and seventeenth-century Italy. Indeed, the considerable variation in mortality across relatively small distances is a conundrum remarked on and studied by Italian scholars (Cipolla, 1981; Alfani, 2013). Factors such as the timing of when the plague struck, geography and topography, the weather, and governance are all likely to have played a role. After surveying the data for a range of central-northern Italian cities-and in particular the neighbouring cities of Prato and Pistoia in 163031-Cipolla cautiously concluded "one has to be cautious about generalizations” (1981, pp. 84-85, 108).

\section{Did Public Action Matter?}

Why did plague recede in Western Europe during the sixteenth and seventeenth centuries? Why had it not done so earlier? After rejecting as likely factors the disappearance of the black rat (rattus rattus), environmental improvement, and changes in the nature of the disease, Slack (1981; see too 2012) opted for increasingly effective public action in the form of quarantining, removing foul-smelling refuse, and draconic measures against infringement. Such action, which is likely to have reduced the likelihood of transmission from fleas (and lice) to humans, required credible sanctions and a degree of public support. The effectiveness of public health measures depended on being ready, eliminating corruption in the forms of breaching quarantines, concealing deaths, deliberate misdiagnoses of plague cases, and anti-social behaviour in general (Cipolla, 1979, p. 20). A local study of the last outbreaks of plague in Leicester, pointing out that the town had fared better than neighbouring towns such as Loughborough and Melton, attributed this to "the stringent regulations enforced during the time of plague [...] a benefit as well as a credit to her inhabitants" (Wilshere, 1968-69, p. 64).

Even Benedictow (2004, p. 95) concedes the role of Milan's ruthlessly effective Visconti rulers in saving that city from plague in 1348-50-though plague would return there with a vengeance later. In Milan, the conviction-not prevalent at the time-that plague was contagious led to efforts at controlling the movements of contacts. But public action can claim few other victories in 1348-50. In Florence (in Boccaccio's words) "huge amounts of filth were removed from the city by officials

\footnotetext{
${ }^{11}$ The terms in inverted commas are Payne's (foreword to Boghurst, 1894, p. xiv).
}

charged with that task; sick people were forbidden to enter the city; advice was given on how to stay healthy; devout persons made humble supplication to God not once but many times, in processions and by other means", but the plague had its way in an "almost miraculous manner".

Quarantining and maritime cordons came later; the first lazaretti were those in Ragusa (1377) and Venice (1423) (Tognotti, 2013). The policy of isolating suspected plague victims in lazaretti was based on the (false) presumption that the disease was spread from person to person, but may well have worked to the extent that lazaretti were located in areas that were less flea- and rat-infested than the streets on which plague raged; but the English policy of shutting "sound people" in their homes when a death had occurred instead of allowing them escape infection may well have been counterproductive (Payne, 1894, p. 99; Slack, 2012, pp. 83-84). Cipolla has described in some detail how municipal action-through the enforcement of quarantines, the funding of lazaretti, improvements in public hygiene, the banning of super-spreading events such as processions and festivals, and so on-reduced the threat of plague in parts of seventeenth-century Italy. The improvements were by no means comprehensive or universal: while the cities of Tuscany escaped rather lightly in 1629-30, plague killed one in three in Venice and three in five in Verona (shades of Benedictow!). Half the population of Genoa and Naples succumbed in 1656-57, while public action limited the mortality to one in ten in Rome (Alfani, 2013). Other institutional responses to plague included the London Bills of Mortality (continuously from 1603) and bans on processions and other large congregations of people ${ }^{12}$.

Although what caused plague was not understood at the time, Cipolla depicts the acceptance of the measures associated with effective public action in northern and central Italy as a victory of science over superstition. How very different it was in Moscow at the height of the plague outbreak of 1771 when "an outrageous mob broke open the pest-houses and the quarantine-hospitals, renewing all the religious services which it is customary with them to perform at the bed-side of the sick, and digging up the dead bodies and burying them afresh in the city [...]. They began again to embrace the dead, despising all manner of precaution" (de Mertens, 1799, p. 23). These unfortunates believed that precaution and resistance against the plague, a divine punishment, was futile. This is reminiscent of reports from western Africa in 2014-15. Ebola took hold in Sierra Leone in May 2014 just after hundreds of people attended the death of a local faith healer who had succumbed to the disease. Traditional burial customs were also blamed for the early spread of the disease in Guinea (WHO, World Health Organization, hereafter); indeed, a WHO official declared that "fear and resistance from locals were more powerful drivers of the epidemic than any mistakes by the WHO or anyone else"13 (Trenchard, 2015; Cheng et al., 2015).

On the eve of the Ebola crisis Sierra Leone had 0.022 physicians per 1,000 inhabitants, Liberia 0.014 , and Guinea 0.115 . Compare this to Ireland's 0.35 physicians and surgeons per 1,000

\footnotetext{
${ }^{12}$ In 1604 the authorities in London ordained that theatres should close once the number of plague deaths in the Bills exceeded thirty (Shapiro, 2015).

${ }^{13}$ Chicago Tribune, "AP Investigation: Bungling by UN agency hurt Ebola response”, 22 September 2015.
} 
inhabitants on the eve of the Great Famine of the 1840s. Although the medics behind these numbers did not know how to cure either plague or Ebola, the numbers also reflect broader medical infrastructures. All three affected countries had per capita income levels about one\% of Ireland's; by the same token they were much poorer than, say, seventeenth-century Italy or England, though they had also been growing much faster in recent years. Given the economic context, some will ask how come the epidemic was so limited and vanquished so quickly! ${ }^{14}$

The goal of international relief in 2014-15 was to compensate for frail public health infrastructures and widespread destitution (Jerving, 2014). However, given the huge transfers involved, corruption was inevitable. In November 2014 in Sierra Leone, when health workers protested violently at not being paid, all a spokesman for the National Ebola Response Centre could offer was that "somebody somewhere needs to be investigated (to find out) where these moneys have been going".

The disease that had already killed about sixty people in Guinea since late 2013 was identified as Ebola on 22 March 2014. At that time the WHO characterized it as "an outbreak of limited geographic area and only a few chains of transmission", and this assessment tallied with evidence on earlier outbreaks of Ebola in central Africa (Foulkes, 2014). However, by late May the disease had reached Sierra Leone and on 8 August 2014, by which time the death toll had reached nearly one thousand, the WHO declared the outbreak an "international health emergency". In the following weeks alarming forecasts of the likely death toll from Ebola spurred the international community to action. By May 2015 such transfers exceeded $\$ 3$ billion, more than $30 \%$ of the combined GDP of the three recipient economies.

Still, critics accused the WHO and the international community of a weak and delayed response. Médecins sans frontières, who provided most of the frontline defence against Ebola at the outset, accused the authorities in Guinea and Sierra Leone of seeking to conceal the outbreak; the biotech company Metabiota, which was employed to monitor the crisis in Sierra Leone, of refusing to share crucial data about the progress of the outbreak; and the WHO of prevarication ${ }^{15}$. The international community was rather slow to "wake up" about Ebola ${ }^{16}$. Not surprisingly, the speed with which epidemic was eventually controlled led to speculation regarding what might have been achieved had large-scale intervention begun a few months earlier (Stack et al., 2014). Discussions of the role on official interventions have been equally passionate during the COVID crisis. The significant contrasts in incidence and fatalities across Europe have been linked to policy; equally striking contrasts in the death rates across US cities during the flu pandemic of 1918-19 have been attributed to public action by both medical scientists and economists (Markel et al., 2007; Barro 2020).

\footnotetext{
${ }^{14}$ In 2013 Gross National Income per capita, adjusted for PPP, was $\$ 720$ in Sierra Leone; $\$ 480$ in Guinea; and \$400 in Liberia (World Bank). Nigeria's more advanced health infrastructure helped it stop Ebola from spreading in late 2014 (The Economist, 20 October 2014).

${ }^{15}$ See: http://pulitzercenter.org/reporting/africa-sierra-leone-ebola-epidemic-health-system-financing-money-aid (Cheng et al., 2018).

${ }^{16}$ For example, there were only 8 references to "Ebola" in the Irish Times before the end of June 2014. The first reference on April $1^{\text {st }}$ referred to an epidemic claiming eighty lives in Guinea, while a feature on Médecins sans frontières on June $21^{\text {st }}$ mentioned Ebola only in passing.
}

\section{The Cure}

Like plague in the past, the recent Ebola outbreak inspired fear and panic because of its lethality, its long incubation period (WHO Ebola Response Team 2014; Van Kerkhove et al., 2015), and exclusive reliance on non-pharmaceutical interventions. The elimination of plague as a threat across most of the globe relied on preventive rather than curative measures, and it took centuries for those preventive measures to become fully effective. ${ }^{17}$ One of the main defences against its spread, quarantine, involved isolating victims for a biblical forty days-a big multiple of plague's incubation period of 2 to 6 days (which, of course, was not known or understood at the time $)^{18}$.COVID-19, too, has a relatively long incubation period. Unlike plague and Ebola it can be asymptomatic, which makes containment more challenging. As with COVID-19 quarantine was also a key weapon against Ebola; a precautionary 21-day quarantine is stipulated for those who have been in close contact with an Ebola victim. In October-November 2014 the publication of a paper by Haas (2014) arguing that a 21-day isolation period was too short led to a flurry of (mainly uninformed) hysterical commentary regarding the dangers posed by U.S. health workers returning home from western Africa (Jantz, 2014). Policy makers ignored this panic, recognizing the danger that draconian quarantines would deter volunteers and increase avoidance ${ }^{19}$.

Yersin's identification of the plague bacillus, pasteurella pestis, in 1894 enabled the Russian-born microbiologist Haffkine to produce his anti-plague vaccine after just three months of intensive work in a makeshift laboratory in Bombay in January 1897. Haffkine had previously produced an effective anti-cholera vaccine in Pasteur's laboratory in Paris and so, once the Yersinia pestis bacillus had been identified, producing a vaccine based on heat-killed $Y$. pestis cultures was well within his capacity. After minimal trials, the new vaccine was pronounced ready for use. Unpleasant side effects lessened its appeal but it was effective in reducing the incidence and lethality of disease (British Medical Journal, 1900; Meyer et al., 1974).

As with plague before Haffkine's discovery, there was no therapeutic cure for Ebola during the epidemic of 2014-15. One of the impressive by-products of that epidemic was the final release of a highly effective vaccine. The clinical discovery of VSV-EBOV dates back to 2003, when scientists working for the Canadian Public Health Agency produced a drug that was effective in protecting rhesus monkeys. Had Ebola struck in the 1890s it is possible that a similar drug would have been discovered, in which case the authorities would have gambled on its immediate use, as happened in the case of Haffkine's vaccine.

However, before the latest Ebola outbreak the Canadian government had merely patented the VSV-EBOV vaccine and presented vials of it to the WHO to try out on volunteers. The Ebola crisis prompted the Merck Group to buy the commercial

\footnotetext{
17 That is, as distinct from eradication, which means completely eliminating the existence of the organism, as in the case of smallpox in 1977 and Rinderpest as recently as 2013. I am grateful to Monica Green for insisting on the distinction.

${ }^{18}$ Compare the more sensible nine-day quarantine imposed by the authorities in Yumen City in July 2014 (Kaiman, 2014).

${ }_{19}$ Breaking news in mid-October 2015 that the virus persisted in some survivors of Ebola long after their recovery raised new fears (e.g. The Guardian, 17 October 2015). The WHO's response, rightly, was that there was no need for panic (WHO, 2016).
} 


\section{GDP Growth 2010-2018}

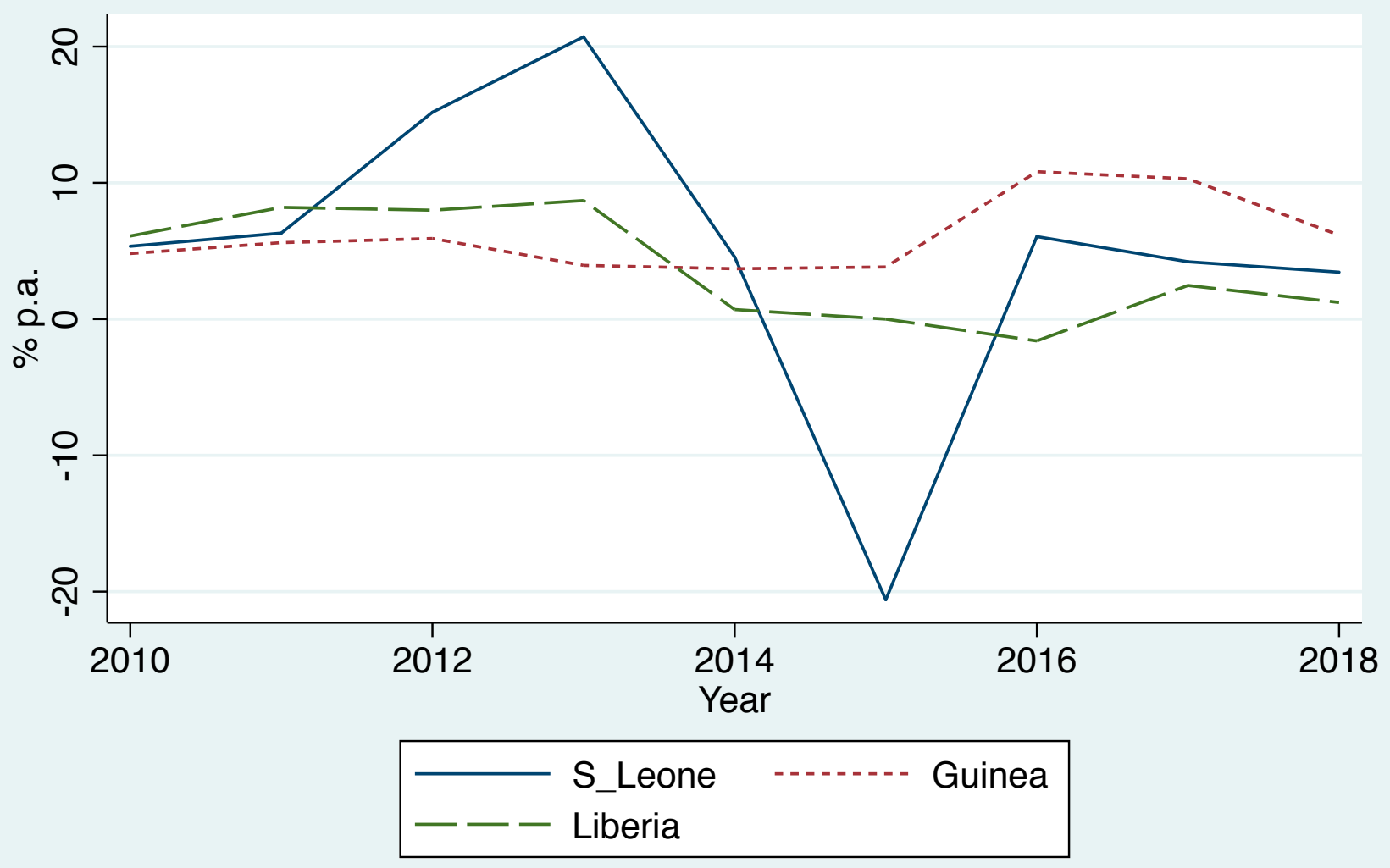

\section{Source: World Bank}

Figure 2. GDP Growth Per Annum 2010-18 in the Affected Economies.

rights to a VSV-EBOV from a small biotech company in November $2014^{20}$. By April 2015 Merck were organizing Phase 3 trials in Guinea. Although the crisis was almost over by the time the vaccine was ready for use, the speed with which it was developed is nonetheless rather impressive. Five years later, the current COVID crisis prompted a similar frantic search for a vaccine, with researchers seeking to achieve in months what would normally take several years. In late July 2020140 vaccines were in preparation and about two dozen were already being tested on people (Gallagher, 2020).

\section{The Economic Consequences of the Black Death and Ebola}

In October 2014 the World Bank predicted that Ebola would cost the three affected countries US $\$ 25$ billion in economic losses in 2015. That would have been equivalent to almost twice their combined GDPs, surely enough to cripple them economically for years to come. By January 2015 that prediction had been reduced to a still significant US $\$ 1.6$ billion, equivalent to about $12 \%$ of combined GDPs. The most recent estimates (see Figure 2) are much more sanguine, implying

${ }^{20}$ The initial discovery, by Canada's Public Health Agency, predated the latest crisis; they had sold the commercial rights to a small U.S. biotech company NewLink in 2010. that the impact of Ebola on the level of economic activity has been minor and will be temporary. The significant drop in GDP in Sierra Leone, by far the most dynamic of the three economies, in 2014 was almost entirely due the global collapse in iron ore prices rather than to Ebola (World Bank, 2015a, 2015b).

Analogous estimates of the economic impact of the Black Death are impossible, but that impact has nonetheless been the subject of extended debate among economic historians. Elementary Malthusian economics predicts that an exogenous shock such as the Black Death, that reduces population but leaves the capital stock and other resource endowments intact, will result in reduced output but an increase in wages relative to other factor payments (Hirshleifer, 1968; Le Roy Ladurie, 1974, pp. 40-50; Clark 2001). And there can be no doubt but that the first attack of the Black Death in western Europe resulted in significantly improved living standards for most survivors, while reducing urbanization levels and shifting the balance between crop cultivation and pasture in the countryside (e.g. Campbell, 2006; Malanima, 2012). Labour's gain “was to prove a potent driving force behind revolutionary changes in economic and social institutions, including the decline of serfdom and feudalism, and a golden age for peasants and labourers" (Hatcher, 2008, p. 321). Some go further, holding that high wages led to labour saving technologies such as the Gutenberg printing press; or crediting the Black Death with leading to, or being indirectly responsible for, an "industrious revolution", an industrial revolution, or the European Marriage 
Pattern (e.g. Pamuk, 2007; Koyama, 2012; Voigtlaender and Voth, 2013).

Evidence of the impact of the Black Death on income or wealth distribution is growing. However, Alfani (2015) and Alfani and Ammanati (2017) report a significant reduction in wealth inequality in north-central Italy in the wake of the mid-fourteenth century Black Death, a finding replicated by Prados de la Escosura et al. (2020) for Spain.

There is also general agreement that it took the population of Europe a long time to recover its pre-plague level, partly because plague kept returning but also because, in some countries at least, of incessant warfare in the decades and centuries that followed. According to Broadberry et al. (2015) England's population reached its post-1348 nadir a century later (c. 1450), three-fifths below its peak on the eve of the Black Death; it would not reach that peak again until the late 1620 s.

The economic and demographic impact of subsequent outbreaks could be much be less dramatic, as highlighted by the case of London. This is seen in the absence of any significant "plague" effect on wages between the mid-sixteenth and mid-seventeenth centuries (Cummins et al., 2015; Boulton 1996). Such was the power of the city to attract labour from the countryside that the last epidemic of 1665 had no appreciable impact on wage levels. The remarkable power of the metropolis to attract labour in the wake of plague, noted by Graunt (1676 [1899], p. 367) at the time, is indicated by its ability to make good so quickly after 1665 one hundred thousand lives lost, even though the total number of young adults living outside London at that time that cannot have numbered much more than a million. The elasticity of labour supply is also indicated by the speed with which new apprentices replaced those who had succumbed (Table 3 ). The last outbreaks of plague in England left no appreciable traces because they were largely confined to urban areas, particularly the metropolis. Still, the welfare gains from the eradication of plague were substantial (Ó Gráda, 2016).

Two important reservations temper the traditional Malthusian account of the post-Black Death era. First, the landed elite everywhere naturally resisted improvements in labour's status, sometimes violently, and with varying success. In eastern Europe this led to what Friedrich Engels dubbed a "second serfdom". Second, the de-urbanization that followed mortality and emigration reduced the volume of both internal and international trade. This may well have led to some diseconomies of scale, with the result that although the lot of the landless labourer improved, the overall state of the economy may not have. This point is supported by Prados de la Escosura et al., (2020) concerning the effects of the Black Death in Spain; they argue that in sparsely populated countries characterised as frontier economies, the effects of the Black Death were negative for incomes per head. Similar trends are observed after the fourteenth century outbreak in Sweden by Krants (2017) probably for the same reasons. In sum, in some areas the demographic decline relieved Malthusian pressures, but it worked in a different way in areas with low population density.

This is closer to the scenario recently been proposed for Italy, where the impact of plague in the seventeenth century was heavy and pervasive, and affected both rural and urban areas. Plague has been blamed for turning "one of the wealthiest areas of Europe", and one with a "solid economy", into an economic backwater (Alfani, 2013; see too Alfani and Per- coco, 2019). In Italy the plague outbreaks of $1629-30$ and the 1650 s, unlike that of 1348 , brought no increase in real wages in its wake (Malanima, 2007). Why the difference? One hypothesis is that the seventeenth-century population loss slashed internal aggregate demand at a time when increasing protectionism was reducing foreign demand. The resultant fall in labour supply thus generated a negative productivity shock by depriving Italy of scale economies that would prove impossible to recover. Given the small size of production units in this era, such economies at the level of the individual firm can hardly have mattered much: but the loss of external economies in realms such as communications and urban services is plausible, given the decline in both the size of several of Italy's major cities and their share of total population (Malanima, 2005, p. 103).

A second argument is that the sheer size of the seventeenth century epidemics in Italy meant that skilled and comfortably off inhabitants were not immune, so that there was an attendant adverse impact on human capital. This is by no means implausible; the starkly different outcomes in the fourteenth and seventeenth centuries might be explained by the universality of the former outbreak compared to the local but very severe character of the Italian outbreaks of the seventeenth century, which placed Italy at a serious competitive disadvantage in their aftermath.

\section{Table 3}

Average number of apprentices enrolled annually before and after three mortality crises in London

\begin{tabular}{|ccc|}
\hline 5 years before & 3 years after & \% change \\
\hline Influenza, $1557-9$ & & \\
\hline 314 & 520 & 66 \\
\hline Plague, 1593 & & 51 \\
\hline 1,039 & 1,574 & \\
\hline Plague, 1603 & & 74 \\
\hline 1,439 & 2,505 & \\
\hline
\end{tabular}

Source: Rappaport (1989, p. 75).

\section{A Final Reflection}

Despite the major differences between them, Yersinia pestis and Ebola share many resonances. The campaign to contain and eradicate Ebola-and the attendant red tape and corruption-recalls the varied attempts by the authorities at ridding Western Europe of plague. Later efforts to control plague had an international dimension: the work of Haffkine, a Russian Jew born in Odessa, in Bombay was funded by the local authorities and by the Aga Khan and plague's virtual eradication in pre-independence India owed much to colonial policies (Harrison, 1994, pp. 152-58). Today the resources and knowledge available for campaigns against epidemics like plague and Ebola are global rather than local. In the case of Ebola, NGOs such as Médecins sans frontières, institutions such as the WHO, and the governments of the countries affected combined in bringing the 2014-15 epidemic under control.

According to WHO data the epidemic had caused 11,313 deaths up to mid-October 2015, by which time the crisis had 
been stayed, with only 23 deaths since the end of August. The number is very modest compared to, say, estimates of famine deaths in Somalia in 2011-12 or of deaths from malaria in sub-Saharan Africa in 2014 (0.4 million), yet the global impact of Ebola was far greater ${ }^{21}$.

At the height of the Ebola crisis the Harvard global health specialist Paul Farmer (2014) insisted that "if patients are promptly diagnosed and receive aggressive supportive careincluding fluid resuscitation, electrolyte replacement and blood products-the great majority, as many as $90 \%$, should survive". Easier said than done, given the fears generated by Ebola, and the primitive health infrastructures (e.g. in Sierra Leone "Most hospitals and clinics don't have running water, and some don't have electricity" (Maxmen, 2015)) and the rickety economies of the counties in question ${ }^{22}$. Yet how many lives might have been spared by a prompter response or by extra funding remains to be discovered (DuBois et al., 2015).

\section{Bibliography}

Alexander, J. T., 2003. Bubonic Plague in Early Modern Russia: Public Health and Urban Disaster. Oxford University Press, Oxford.

Alfani, G., 2013. Plague in seventeenth-century Europe and the decline of Italy: an epidemiological hypothesis. European Review of Economic History, 17 (4), 408-430.

Alfani, G., 2015. Economic Inequality in Northwestern Italy: a Long-Term View (Fourteenth to Eighteenth centuries). Journal of Economic History, 75 (4), 1058-1096.

Alfani, G., and Ammannati, F., 2017. Long-term trends in economic inequality: the case of the Florentine state, c. 1300-1800'. Economic History Review, 70 (4), 1072-1102.

Alfani, G. and Murphy, T., 2017. Plague and Lethal Epidemics in the Pre-Industrial World. Journal of Economic History, 77 (1), 314-343.

Alfani, G. and Bonetti, M., 2019. A survival analysis of the last great European plagues: the case of Nonantola (Northern Italy) in 1630. Population Studies, 73 (1), 101-118.

Alfani, G. and Percoco, M., 2019. Plague and long-term development: the lasting effects of the 1629-30 epidemic on the Italian cities. Economic History Review, 72 (4), 1175-1201.

Álvarez Nogal, C. and Prados de la Escosura, L., 2013. The Rise and Fall of Spain (1270-1850). Economic History Review, 66 (1), 1-37.

Ayyadurai S., Sebbane F., Raoult D. and, Drancourt, M., 2010. Body Lice, Yersinia pestis Orientalis, and Black Death. Emerging Infectious Diseases, 16 (5), 892893.

Barro, R. J., 2020. Non-pharmaceutical interventions and mortality in U.S. cities during the great influenza pandemic, 1918-1919. CESifo Working Paper Series, 8245.

Benedict, C. A., 1996. Bubonic Plague in Nineteenth-century China. Stanford University Press, Stanford.

Benedictow, O., 2004. The Black Death 1346-1353: A Complete History. Boydell Press, Woodbridge.

Benedictow, O., 2005. The Black Death; the greatest catastrophe ever. History Today, 55 (3). [available at: https://www.historytoday.com/archive/ black-death-greatest-catastrophe-ever].

Butler, T., 2009. Plague into the $21^{\text {st }}$ century. Clinical Infectious Diseases, 49 (5), 736-742.

${ }^{21}$ Put at 0.26 million by Checchi and Robinson (2013); for a few caveats see Ó Gráda (2015, pp. 181-183).

${ }^{22}$ These included both the fear of being infected and that of being isolated. As in the case of plague in western India in the late 1890s some of those living in Ebola-affected areas in 2014 believed that health workers were spreading the disease. In the US, where an Ebola outbreak was never a serious possibility, one poll in October 2014 suggested that nearly two-thirds of the population feared such an outbreak while another indicated that nearly half feared that a family member would contact Ebola (Jantz, 2014).
Boghurst, W. 1894 [1666]. Loimographia, an Account of the Great Plague of London in the Year 1665: Now Printed for the First Time. Ed. Joseph Frank Payne. Shaw, London [http://ocp.hul.harvard.edu/dl/contagion/004109751].

Boulton, J., 1996. Wage labour in seventeenth-century London. Economic History Review, 49 (2), 268-290.

Broadberry, S., Campbell, B., Klein, A., Overton, M., and Van Leeuwen, B., 2015 British Economic Growth 1270-1870. Cambridge University Press, Cambridge.

Brett-James, N. G., 1935. The Growth of Stuart London. Allen \& Unwin, London.

British Medical Journal., 1900. Report of The Indian Plague Commission On Haffkine's Antiplague Inoculation, 1(2043), 455-459, 24 February.

Brown, B. W., 1913. Plague: A Note on the History of the Disease in Hongkong. Public Health Reports, 28 (12), 551, 557, 21 March.

Campbell, B., 2006. English Seigneurial Agriculture 1250-1450. Cambridge University Press, Cambridge.

Campbell, B., 2016. The Great Transition: Climate, Disease and Society in the Late-Medieval World. Cambridge University Press, Cambridge.

Checchi, F. and Robinson, W. C., 2013. Mortality among populations of southern and central Somalia affected by severe food insecurity and famine during 2010-2012. FAO, Rome.

Cipolla, C., 1973. Cristofano and the Plague: a Study of the History of Public Health in the Age of Galileo. Collins, London.

Cipolla, C., 1979. Faith, Reason and the Plague: a Tuscan Story of the Seventeenth Century. Harvester Press, Brighton.

Cipolla, C., 1981. Fighting the Plague in Seventeenth-Century Italy. University of Wisconsin Press, Madison.

Cheng et al., 2018. "AP investigation". Out of frustration at reports of corruption, USAID devised a corruption hotline [available at: https://oig.usaid.gov/ node/1791].

Cheng, M., Satter, R., and Larson, K., 2015. "AP investigation: bungling by UN agency hurt Ebola response", AP The Big Story, 20 September.

Clark, G., 2007. The long march of history: farm wages, population, and economic growth, England 1209-1869. Economic History Review, 60 (1), 97-135.

Clark, G., 2001. Microbes and markets: was the Black Death an economic revolution? [available at: http://www.econ.ucdavis.edu/faculty/gclark/papers/ black1.pdf].

Cohn, S. K., 2005. Review of Benedictow [2004]. New England Journal of Medicine, 352, 105455.

Cohn, S. K., 2008. Epidemiology of the Black Death and Successive Waves of Plague. Medical History, 27 (Supplement), 74-100.

Corsi, J. R., 2014. "1.2 million Ebola deaths projected in 6 months", WND, 12 September [available at: http://www.wnd.com/2014/09/1-2-million-ebola-deaths-projected-in-6-months/\#HjwZ3ViocjMOqe0R.99].

Crespo, F. and Lawrenz, M. B., 2014. Heterogeneous immunological landscapes and medieval plague: an invitation to a new dialogue between historians and immunologists. The Medieval Globe. I, 229-58 [available at: https://www. academia.edu/10187036/_Pandemic_Disease_in_the_Medieval_World_Rethinking_the_Black_Death_-_edited_by_Monica_H._Green].

Cummins, N, Kelly, M., and Ó Gráda, C., 2016. Living standards and Plague in London, 1560-1665. Economic History Review, 69 (1), 3-34.

De Mertens, C., 1799. An Account of the Plague which Raged in Moscow, in 1771 Rivington, London.

DeWitte, S. N. and Wood, J. W., 2008. Selectivity of the Black Death with respect to preexisting health. Proceedings of the National Academy of Sciences, 105, 1436-1441.

DeWitte, S. N. and Hughes-Morey, G., 2012. Stature and frailty during the Black Death: the effect of stature on risks of epidemic mortality in London, A.D. 1348-1350. Journal of Archaeological Science, 39 (5), 1412-1419.

DeWitte, S. N., 2014. The anthropology of plague: insights from bioarchaeological analysis of epidemic cemeteries. The Medieval Globe. I, pp. 97-124 [available at: https://www.academia.edu/10187036/_Pandemic_Disease_in_the_Medieval_World_Rethinking_the_Black_Death_-_edited_by_Monica_H._Green].

DeWitte, S. N. and Slavin, P., 2013. Between famine and death: England on the eve of the Black Death. Evidence from paleoepidemiology and manorial accounts. Journal of Interdisciplinary History, 44, 1-25.

Drancourt, M., Houhamdi,L. and Raoult, D., 2006. Yersinia pestis as a telluric, human ectoparasite-borne organism. Lancet Infectious Diseases, 6, 234-41.

DuBois, M. And Wake, C (with Sturridge, S. and Bennet, C.), 2015. The Ebola response in West Africa Exposing the politics and culture of international aid. ODI: Humanitarian Policy Group Working Paper, October.

Farmer, P., 2014. Diary. London Review of Books, 36 (20), 38-39.

Fee, W. T., 1901. Plague in the Presidency of Bombay from September 1896 to January 19 1900. Public Health Reports, 15 (17), 1018-22.

Fink, S., 2014. Ebola's mystery: one boy lives, another dies. New York Times, 9 November. 
Foulkes, I., 2014. Ebola: WHO under fire over response to epidemic. BBC News, 20 October [available at: http://www.bbc.com/news/world-europe-29691044].

Gallagher, J., 2020. Coronavirus vaccine: When will we have one? BBC News online, 21 July [available at: https://www.bbc.com/news/health-51665497].

Glennerster, R., McLeod, H. and Suri,T. 2015. How bad data fed the Ebola epidemic. New York Times, 30 January.

Grady, D., 2014. Ebola Cases Could Reach 1.4 Million Within Four Months, C.D.C. Estimates. New York Times, 23 September

Graunt, J., 1676 [1899]. Natural and Political Observations Upon the bills of Mortality, $5^{\text {th }}$ ed. In: C. H. Hull (ed.). The Economic Writings of Sir William Petty, vol. 2, Cambridge University Press, Cambridge, pp. 315-435.

Green, M. H., 2015. The Black Death and Ebola: On the Value of Comparison. In: Green, M. H. (ed.). Pandemic Disease in the Medieval World: Rethinking the Black Death, TMG Occasional Volumes 1. Kalamazoo, MI, and Bradford, UK: Arc Medieval Press, pp. ix-xx.

Haas, C. N., 2014. On the quarantine period for Ebola virus. PLOS Current Outbreaks, 14 October.

Haensch, S., Bianucci, R, Signoli, M., Rajerison, M. et al., 2010. Distinct clones of Yersinia pestis caused the Black Death. PLoS Pathogens, 6 (10) [available at: https://journals.plos.org/plospathogens/article?id=10.1371/journal. ppat.1001134\#abstract1].

Harrison, M., 1994. Public Health in British India: Anglo-Indian Preventive Medicine 1859-1914. Cambridge University Press, Cambridge.

Harvey, G., 1769. An Historical Narrative of the Great Plague at London. Nicholl, London.

Hatcher, J., 1977. Plague, Population and the English Economy 1348-1530. Macmillan, London.

Hatcher, J., 1994. England in the Aftermath of the Black Death. Past \& Present, 144, 3-35.

Hatcher, J., 2008. The Black Death: The Intimate Story of a Village in Crisis, 13451350. Phoenix Books, London.

Herlihy, D., 1965. Population, Plague and Social Change in Rural Pistoia, 12011430. Economic History Review, 18, 225-244.

Hirshleifer, J., 1966. Disaster and recovery: the Black Death in western Europe. RAND Corporation, Santa Monica.

Horrox, R., 2006. Review of Benedictow [2004]. English Historical Review, 121 (490), 197-199.

Hufthammer, A. K. and Walløe, L., 2013. Rats cannot have been intermediate hosts for Yersinia pestis during medieval plague epidemics in Northern Europe. Journal of Archaeological Science, 40, 1752-1759.

Jantz, G., 2014. Which Is Worse: Ebola or Fear-bola? Ebola hysteria is the real epidemic. Psychology Today, 28 October.

Jerving, S., 2014. Why Liberians thought Ebola was a government scam to attract western aid: decades of corruption have left Liberians suspicious of their government. The Nation, 16 September.

Johnson, D., 2014. Behind the Changing Forecast for Ebola Infections. Time Magazine, 10 December.

Kaiman, J., 2014. In China a single plague death means an entire city quarantined. The Guardian, 25 July.

Keene, D., 2001. Growth, modernization and control: the transformation of London's landscape c. 1500-c. 1760. In: Clark, P. and Gillespie, R. (eds.). Two Capitals: London and Dublin, 1500-1840. British Academy, London, pp. 7-38.

Kitamura, M., 2014. Inside an Ebola Protective Suit That Feels 115 Degrees. Bloomberg Business, 23 September.

Kool, J. L., 2005. Risk of Person-to-Person Transmission of Pneumonic Plague. Clinical Infectious Diseases, 40 (8), 1166-1172.

Koyama, M., 2012. The transformation of labor supply in the pre-industrial world. Journal of Economic Behavior and Organization, 81, 505-523.

Krantz, O., 2017. Swedish GDP 1300-1560: A Tentative Estimate. Lund: Lund Papers in Economic History, 152.

Kupferschmidt, K., 2014. Disease modelers project a rapidly rising toll from Ebola. Science Insider, 31 August [available at: http://news.sciencemag.org/ health/2014/08/disease-modelers-project-rapidly-rising-toll-ebola]

Le Roy Ladurie, E., 1974. The Peasants of Languedoc. University of Illinois Press, Urbana, Ill.

Little, L. K., 2011. Plague historians in lab coats. Past \& Present, 213, 267-290.

Malanima, P., 2005. Urbanisation and the Italian economy during the last millennium. European Review of Economic History, 9 (1), 97-122.

Malanima, P., 2007. Wages, productivity and working time in Italy, 1270-1913. Journal of European Economic History, 36 (1), 127-171.

Malanima, P., 2012. The economic consequences of the Black Death. In: Lo Cascio, E. (ed.). L'impatto della "peste antonina". Edipuglia, Bari, pp. 311-28.
Markel H., Lipman, H.B., Navarro, A. et al., 2007. Nonpharmaceutical Interventions Implemented by US Cities During the 1918-1919 Influenza Pandemic. Journal of the American Medical Association, 298 (6), 644-654.

Maxmen, A., 2015. To prevent the next plague, listen to Boie Jalloh, NPR, 8 October [available at: http://www.npr.org/sections/goatsandsoda/2015/10/08/ 446631677/to-prevent-the-next-plague-listen-to-boie-jalloh].

Mengel, D. C., 2007. A plague on Bohemia? Mapping the Black Death. Past \& Present, 211, 3-34.

Meyer, K. F., Cavanaugh, D. C., Bartelloni, P. J., and Marshall, J.D. Jr., 1974. Plague immunization. I. Past and present trends. Journal of Infectious Diseases, 129 (Supplement), pp. S13-S18.

Moote, A. L. and Moote, D.C., 2006. The Great Plague: The Story of London's Most Deadly Year. St. Johns Hopkins Press, Baltimore.

Nathan, R., 1898. The Plague in India 1896, 1897. Vol. 1. GPO, Simla.

Noorthouck, J., 1773. A New History of London, Including Westminster and Southark. Baldwin, London.

Nordrum, A., 2015. Ebola Outbreak: Estimate of 1.4 Million Victims Never Materialized; Now, CDC Rethinks How It Talks About Disease Outbreaks. New York Times, 4 February.

Noymer, A., 2007. Contesting the cause and severity of the Black Death: a review essay. Population and Development Review, 33 (3), 616-627.

Ó Gráda, C., 2015. Eating People is Wrong: Essays on the History and Future of Famine. Princeton University Press, Princeton.

Ó Gráda, C., 2016. Cast Back into the Dark Ages of Medicine? What the Past Can Tell Us about the Challenge of Antimicrobial Resistance. American Journal of Medical Research, 3 (1), 142-173.

Pamuk, S., 2007. The Black Death and the origins of the "Great Divergence" across Europe, 1300-1600. European Review of Economic History, 11 (3), 289-317.

Phipson, E. S., 1923. The pandemic of influenza in India in the year 1918. Indian Medical Gazette, 58 (11), 509-524.

Prados de la Escosura, L., Álvarez-Nogal, C. and Santiago-Caballero, C., 2020. Growth Recurring in Preindustrial Spain: Half A Millennium Perspective. CEPR Discussion Paper, DP14479.

Pryor, E. G., 1975. The great plague of Hong Kong. Journal of the Royal Asiatic Society: Hong Kong Branch, 15, 61-70.

Rappaport, S., 1989. Worlds within Worlds: Structures of Life in $16^{\text {th }}$-Century London. Cambridge University Press, Cambridge.

Rawcliffe, C., James, T., Ormrod, M. y Benetictow, O., 2018. The Black Death: the historians' view. BBC History Magazine, July, pp. 28-32.

Slack, P., 1981. The disappearance of plague: An alternative view. Economic History Review, 34 (3), 469-476.

Slack, P., 2012. Plague: a Very Short Introduction. Oxford University Press, Oxford.

Sengupta, S., 2014. New Ebola Cases May Soon Reach 10,000 a Week, Officials Predict. New York Times, 14 October.

Shapiro, J., 2015. How Shakespeare's great escape from the plague changed theatre. The Guardian, 24 September.

Stack et al., K., 2014. How Ebola roared back. New York Times, 29 December.

The Economist, 2014. How Nigeria stopped Ebola, 20 October.

The Guardian, 2015. How Pauline Cafferkey's Ebola relapse tears up everything doctors thought they knew. 17 October [available at: http://www.theguardian.com/world/2015/oct/16/how-pauline-cafferkeys-ebola-relapse-tearsup-everything-doctors-thought-they-knew]

Tognotti, E., 2013. Lessons from the History of Quarantine, from Plague to Influenza A. Emerging Infectious Diseases 19 (2) [available at: http://wwwnc. cdc.gov/eid/article/19/2/12-0312_article].

Trenchard, T., 2015. Sierra Leone's rich and powerful are breaking the Ebola burial rules. New Republic, 30 June

UN News., 2020. Impacts of COVID-19 disproportionately affect poor and vulnerable: UN chief. 30 June 2020 [available at: https://news.un.org/en/ story/2020/06/1067502 or https://www.theguardian.com/world/2020/ apr/01/poor-and-vulnerable-hardest-hit-by-pandemic-in-spain].

Van Kerkhove, M. D., Bento A.I., Mills, H.L., Ferguson, N. M., and Donnelly C. A., 2015. A review of epidemiological parameters from Ebola outbreaks to inform early public health decision-making. Scientific Data 2: 150019 [available at: http://www.nature.com/articles/sdata201519\#f1].

Voigländer, N. and Voth, H. J., 2012. The Three Horsemen of Riches: Plague, War, and Urbanization in Early Modern Europe. Review of Economic Studies. 80, 774-811.

Weintraub, K., 2014. Ebola Epidemic Could Top a Million Victims If Not Contained, CDC Warns. National Geographic, 24 September [available at: http:// news.nationalgeographic.com/news/2014/09/140923-ebola-virus-west-africa-cdc-projections/].

Wilshere, J. O. E., 1968-1969. Plague in Leicester, 1558-1665. Transactions of the Leicestershire Archaeological and Historical Society. 44, 45-71. 
WHO Ebola Response Team., 2014. Ebola virus disease in West Africa: the first 9 months of the epidemic and forward projections. New England Journal of Medicine 371 (16), 16 October.

WHO, no date. Sierra Leone: a traditional healer and a funeral: more than 300 Ebola cases link back to one funeral [available at: http://who.int/csr/disease/ ebola/ebola-6-months/sierra-leone/en/].

WHO, 2003. Ebola haemorrhagic fever in the Republic of the Congo. (updates 7 May 2003 and 6 January 2004) [available at: www.who.int/csr/don/2003_05_07/en/; www.who.int/csr/don/2004_01_06/en/].
WHO, 2015. Health worker Ebola infections in Guinea, Liberia and Sierra Leone [available at: http://www.who.int/hrh/documents/21 may2015_web_final. pdf].

WHO, 2016. Persistent virus in people recovering from Ebola virus disease [available at: http://www.who.int/csr/disease/ebola/virus-persistence/en/].

World Bank, 2015. Ebola: Most African Countries Avoid Major Economic Loss but Impact on Guinea, Liberia, Sierra Leone Remains Crippling [available at: http://www.worldbank.org/en/news/press-release/2015/01/20/ebola-mostafrican-countries-avoid-major-economic-loss-but-impact-on-guinea-liberia-sierra-leone-remains-crippling] 